Document downloaded from:

http://hdl.handle.net/10251/164825

This paper must be cited as:

Blasco-Brusola, A.; Vayá Pérez, I.; Miranda Alonso, MÁ. (2020). Influence of the linking bridge on the photoreactivity of benzophenone-thymine conjugates. The Journal of Organic Chemistry. 85(21):14068-14076. https://doi.org/10.1021/acs.joc.0c02088

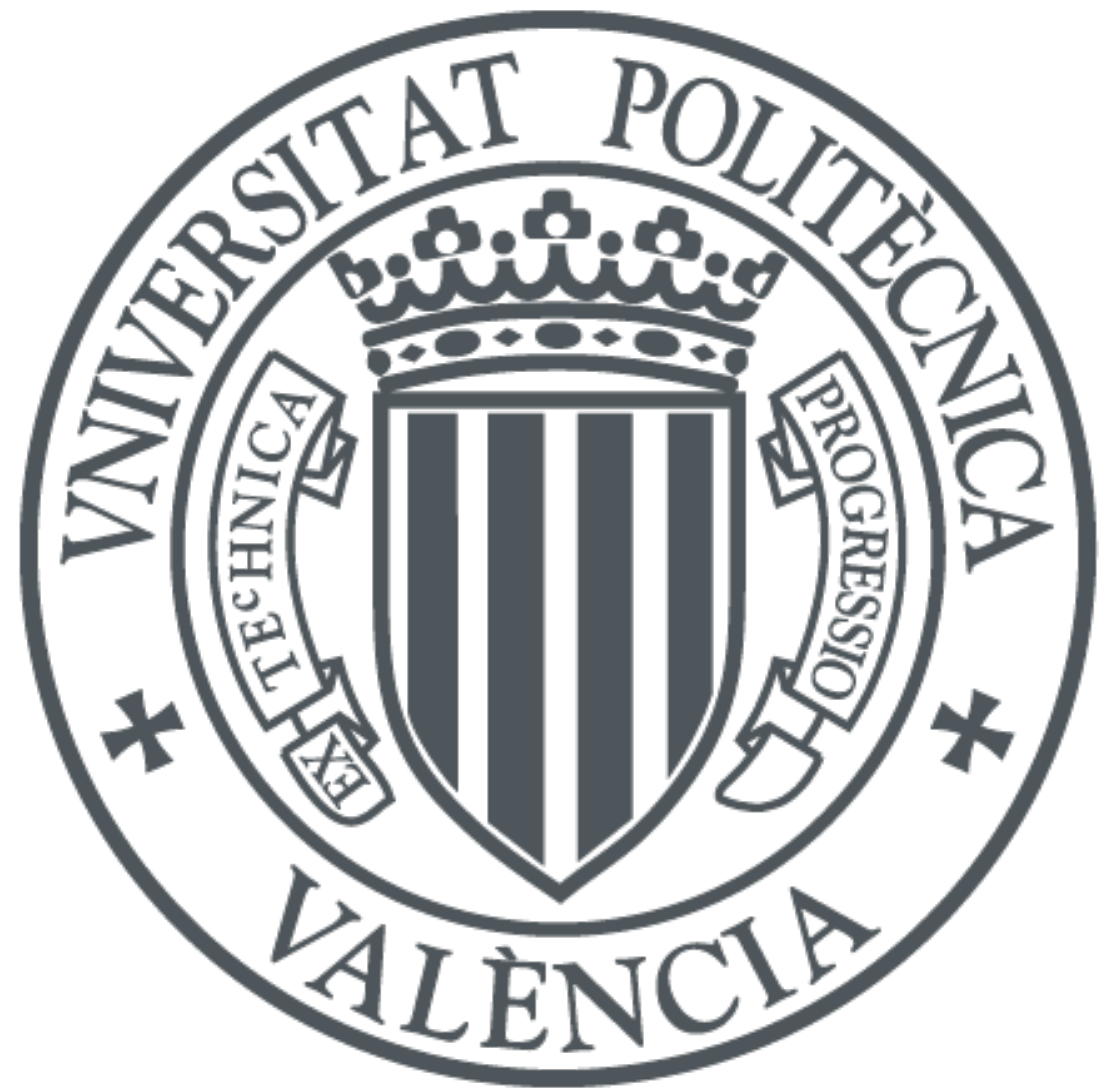

The final publication is available at

https://doi.org/10.1021/acs.joc.0c02088

Copyright American Chemical Society

Additional Information 


\title{
Influence of the Linking Bridge on the Photoreactivity of Benzophe- none-Thymine Conjugates
}

\author{
Alejandro Blasco-Brusola, Ignacio Vayá* and Miguel A. Miranda* \\ Departamento de Química/Instituto de Tecnología Química UPV-CSIC, Universitat Politècnica de València, Camino de \\ Vera $s / n, 46022$ València (Spain) \\ mmiranda@qim.upv.es; igvapre@qim.upv.es
}

KEYWORDS. DNA damage, femtosecond transient absorption, hydrogen abstraction, laser flash photolysis, oxetanes, triplet exciplexes

\begin{abstract}
Benzophenone (BP) is present in a variety of bioactive molecules. This chromophore is able to photosensitize DNA damage, where one of the most relevant BP/DNA interactions occurs with thymine (Thy). In view of the complex photoreactivity previously observed for dyads containing BP covalently linked to thymidine, the aim of this work is to investigate whether appropriate changes in the nature of the spacer could modulate the intramolecular BP/Thy photoreactivity, resulting in an enhanced selectivity. Accordingly, the photobehavior of a series of dyads derived from BP and Thy, separated by linear linkers of different length, has been investigated by steady-state photolysis, as well as femtosecond and nanosecond transient absorption spectroscopy. Irradiation of the dyads led to photoproducts arising from formal hydrogen abstraction or PaternòBüchi (PB) photoreaction, with a chemoselectivity that was clearly dependent on the nature of the linking bridge; moreover, the PB process occurred with complete regio- and stereoselectivity. The overall photoreactivity increased with the length of the spacer and correlated well with the rate constants estimated from the BP triplet lifetimes. A reaction mechanism explaining these results is proposed, where key features are the strain associated with the reactive conformations and the participation of triplet exciplexes.
\end{abstract}

\section{INTRODUCTION}

The interaction of solar UV light with DNA can give rise to chemical modifications in its structure that may result in cell death and eventually in the appearance of cancer. ${ }^{1-2} \mathrm{Di}-$ rect photoinduced damage is mainly associated with the formation of cyclobutane pyrimidine dimers (CPDs) and to a lesser extent pyrimidine (6-4) pyrimidone photoproducts ((6-4)PPs), which are highly mutagenic; ${ }^{3-7}$ in addition, oxidative DNA lesions can also be formed in lower yields. ${ }^{8}$ Formally, CPDs are generated through a [2+2] cycloaddition between two adjacent nucleobases while the (6-4)PPs arise from a Paternò-Büchi $(\mathrm{PB})$ photochemical reaction to form an oxetane intermediate, which rapidly evolves through ring-opening and isomerization to afford the (6-4)PPs as photoproducts. $^{9-10}$ Both lesions, CPDs and (6-4)PPs, can be efficiently repaired by two mechanisms: in humans, the nucleotide excision repair predominates, while in other organisms (i. e. bacteria and plants) the photolyase-mediated mechanism reverses the damage through a photoinduced electron transfer process. ${ }^{11-15}$

Photoinduced damage to DNA can occur not only upon direct absorption of UVB light but also through photosensitization. ${ }^{3,16}$ In this case, excitation of an exogenous or endogenous photosensitizer (PS) at comparatively longer wavelengths leads, after intersystem crossing, to reactive longlived triplet excited states. In this context, some non-steroidal anti-inflammatory drugs (NSAIDs) photosensitize DNA damage upon absorption of UVA light. ${ }^{17} \mathrm{~A}$ typical example is ketoprofen (KP), ${ }^{18-23}$ whose photobehavior can be attributed to its benzophenone (BP) substructure, as the BP chromophore itself is known to elicit DNA damage by photosensitization. ${ }^{24-25}$ Interestingly, this scaffold is present in a variety of drugs, which exhibit a broad range of biological activities such as anticancer, anti-inflammatory, antimicrobial and antiviral. ${ }^{26}$

One of the most relevant interactions in the DNA photosensitization by BP derivatives occurs between the BP chromophore and the thymine (Thy) nucleobase. A simplified mechanism explaining these interactions is shown in Scheme 1. Absorption of UVA-light by BP rapidly generates its excited triplet state $\left({ }^{3} \mathrm{BP}^{*}\right)$, which can mediate formation of ${ }^{3}$ Thy* by triplet-triplet energy transfer (TTET), either directly or through a triplet exciplex ${ }^{3}[\mathrm{BP} \cdots \mathrm{Th}]^{*}$. Subsequently, ${ }^{3}$ Thy* or ${ }^{3}[\mathrm{BP} \cdots \text { Thy }]^{*}$ may react with another thymine moiety leading ultimately to CPDs as formal [2+2] cycloadducts. ${ }^{27}$ Alternatively, ${ }^{3}\left[\mathrm{BP} \cdots\right.$ Thy $^{*}$ can also evolve to oxetane derivatives. Exciplexes of this type have recently been detected in BP-Thy conjugates. ${ }^{28}$ Finally, an electron transfer process may also occur, albeit to a lesser extent, producing oxidative damage. ${ }^{29}$

Scheme 1. Simplified mechanism showing the excited state interactions between BP and Thy, which may finally result in the formation of some photoproducts inducing damage to DNA. 


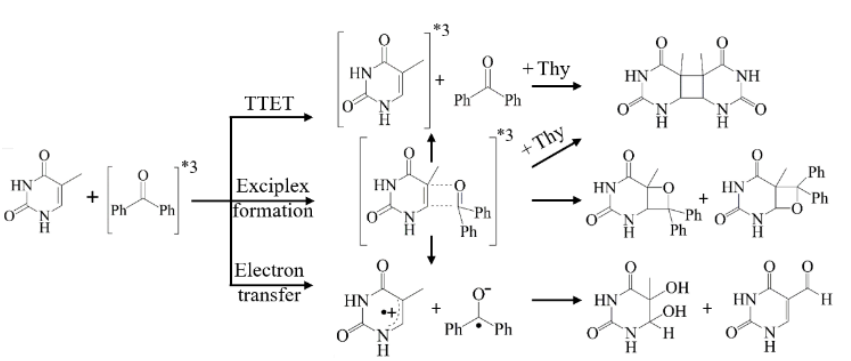

Bichromophoric systems composed of a nucleobase (or nucleoside) covalently linked to a photosensitizer (or a photoactive drug) have been previously used as models to investigate the excited-state interactions underlying photosensitized DNA damage. ${ }^{30-32}$ In particular, the photoreactivity of two dyads containing KP covalently linked to thymidine at positions 5' or 3' of the sugar moiety has been previously investigated..$^{33}$ The behavior of both regioisomers was found to be strongly influenced by the relative spatial arrangement (cisoid or transoid) of the KP and Thy units. Photolysis of the cisoid isomer gave rise to four oxetanes plus two additional photoproducts arising from a formal intramolecular hydrogen abstraction; on the contrary, irradiation of the transoid isomer resulted only in slow polymerization. Accordingly, the ${ }^{3} \mathrm{KP} *$ triplet excited state was markedly shorter-lived in the cisoid isomer, in line with its higher reactivity. In this context, recent theoretical calculations on ligand/DNA interactions have found that photosensitized DNA damage depends on the relative orientation of the chromophore interacting with Thy. ${ }^{34}$

In view of the rich photoreactivity observed for the dyads containing KP covalently linked to thymidine at position 5' of the sugar, which leads to complex photoproduct mixtures, it appeared interesting to investigate whether appropriate changes in the nature of the spacer could modulate the intramolecular BP/Thy photoreactivity, resulting in an enhanced chemo- regio- and/or stereoselectivity. Therefore, with the general goal of getting a better understanding of ligand/DNA interactions, a series of photosensitizer-nucleobase dyads have been designed in the present work (Figure 1) and submitted to a systematic study of their photochemical and photophysical properties, including careful identification of the photoproducts obtained by steadystate photolysis and transient spectroscopic characterization of the reactive triplet excited states in the nanosecond and femtosecond timescales. In dyads D4, D6 and D10 both chromophores are separated by a linear chain composed of four, six or ten linking atoms. In the cisoid dyad D7, which we have reinvestigated for comparison, the BP and Thy units are separated by the sugar moiety, where the cisoid arrangement of BP and Thy can increase the number of reactive conformations with respect to the linear linkers.

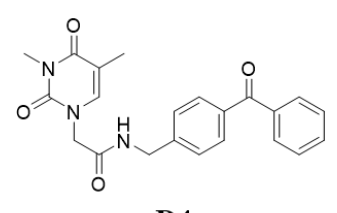

D4

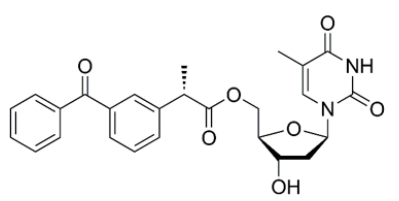

D7

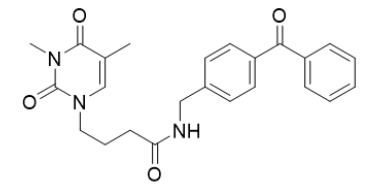

D6

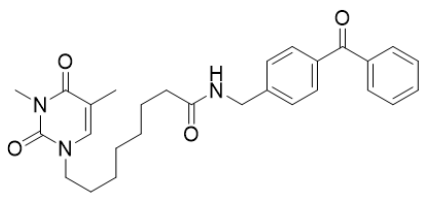

D10
Figure 1. Chemical structure of the investigated dyads.

\section{RESULTS AND DISCUSSION}

The synthesis of the selected dyads is described in detail in the Supporting Information. For D7, the reported synthesis $^{33}$ involves covalent KP linking to the $5^{\prime}$ position of the sugar through an ester bond; by contrast, for the linear dyads D4, D6 and D10 (see Scheme 2), a Thy-derived alkanoic acid of variable length is conjugated with the BP derivative 4-benzoylbenzylamine (BPN) through an amide bond.

Scheme 2. Schematic representation of the synthesis of D4, D6 and D10.

A

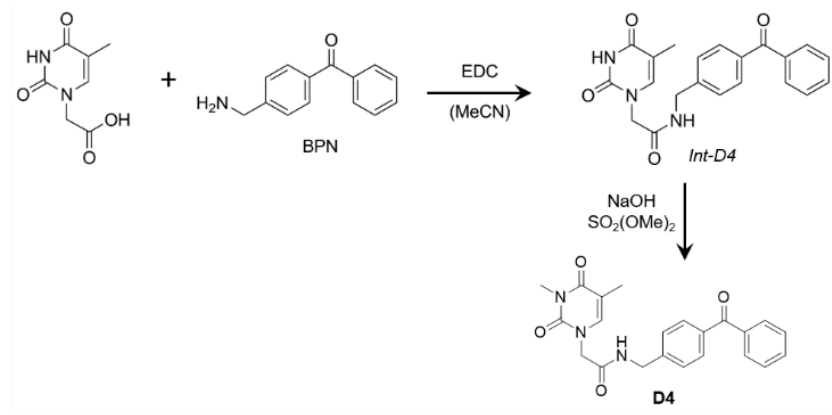

B
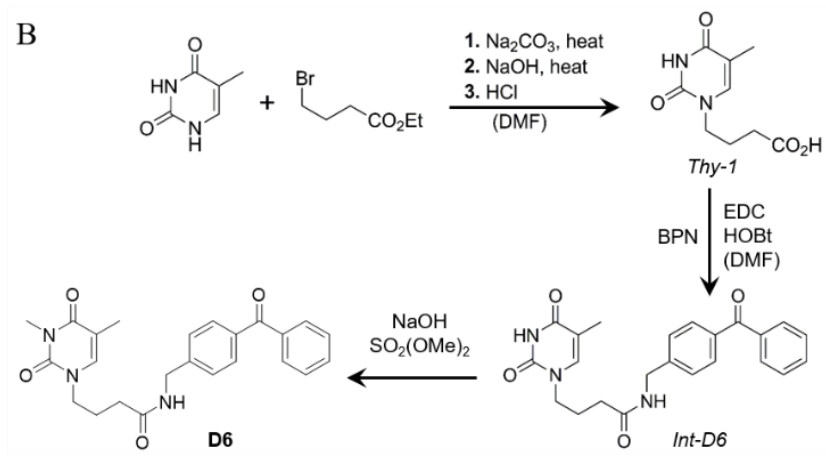

$\mathrm{C}$

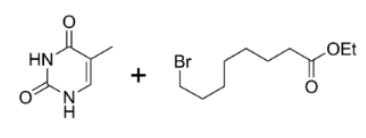

1. $\mathrm{Na}_{2} \mathrm{CO}_{3}$, heat

1. $\mathrm{Na}_{2} \mathrm{CO}_{3}$, heat
2. $\mathrm{NaOH}$, heat
3. $\mathrm{HCl}$

(DMF)

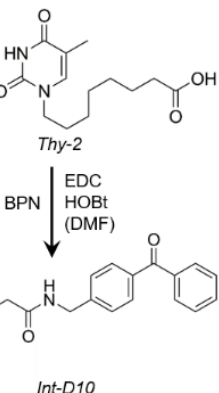


The photoreactivity of the obtained dyads was first investigated by means of steady-state photolysis and transient absorption spectroscopy. Thus, isoabsorptive solutions $(\mathrm{A}=$ 0.05 , concentration $c a .20 \mu \mathrm{M}$ ) of the three new compounds were irradiated in deaerated acetonitrile in a multilamp photoreactor emitting at $\lambda_{\max }=350 \mathrm{~nm}$. The course of the reaction was followed by monitoring the decrease of the UV absorption at $254 \mathrm{~nm}$ (Figure 2), which is mainly associated with the diaryl ketone (see Figure S1 in the Supporting Information).

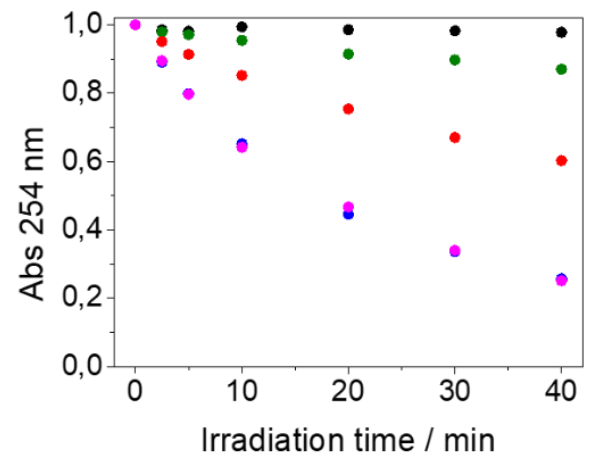

Figure 2. Photochemical reactivity of BPN (black), D4 (green), D6 (red), D7 (blue) and D10 (magenta) followed by the decrease in the absorbance of the carbonyl band at $254 \mathrm{~nm}$ against the irradiation time. Irradiations were performed in deaerated acetonitrile $(\sim 20 \mu \mathrm{M})$ using a multilamp photoreactor $\left(\lambda_{\max }=350 \mathrm{~nm}\right)$ through quartz cells.

A progressive disappearance of the absorption at ca. 254 $\mathrm{nm}$ was observed for the dyads, whereas the reference compound BPN was nearly unreactive under the same conditions (see also Figure S11 in the Supporting Information). The photochemical reactivity followed the order D4 $<$ D6 $<$ $\mathbf{D 1 0} \approx \mathbf{D} 7$. For product studies, higher concentrations of the dyads $(2.6 \mathrm{mM})$ were used. Irradiation of $\mathbf{D} 4$ gave only rise to unidentified polymeric material. By contrast, D6 and D10 led to the formation of well-defined photoproducts that were separated and purified by semipreparative HPLC, and characterized by ${ }^{1} \mathrm{H}$ - and ${ }^{13} \mathrm{C}-\mathrm{NMR}$, as well as HRMS (see details in the Supporting Information). Thus, photolysis of D6 resulted not only in polymerization, but also in the formation of photoproduct PP-D6 (see scheme 3) in very low yields ( $3 \%)$ after HPLC purification, which may arise from a direct $\mathrm{H}$-atom abstraction or through an electron transfer process followed by proton transfer, to afford formal hydrogen abstraction chemistry. The intermediate radical pair contains a Thy-derived radical at the C5-methyl group, which under aerobic conditions would be trapped by oxygen, to give a 5 -formyluracil. Thus, this chemistry would be connected with the oxidative damage to DNA. ${ }^{35}$ However, it should be noted that oxidation of Thy in the biomolecule is less favored than that of the guanine nucleobase, which has the lowest oxidation potential and would be a better electron donor than Thy towards the excited BP moiety. ${ }^{21}$ Conversely, the main photoproduct resulting from irradiation of D10 was an oxetane (Ox-D10), ca. 20\% yield after HPLC purification, which clearly arises from a Paternò-Büchi reaction between the excited carbonyl of BP and the C5=C6 double bond of Thy. The regio- and stereochemistry of $\mathbf{0 x}$ D10 were unambiguously established by X-ray crystallography (see Figure 3). The photoproducts arising from irradiation of D7, namely 0x-D7a, 0x-D7b, 0x-D7c, Ox-D7d, PP-D7a and PP-D7b have been previously characterized; ${ }^{33}$ higher yields were observed for the oxetane formation, while photoproducts PP-D7a and PP-D7b were obtained in lower yields.

Scheme 3. Simplified mechanism for the photoproduct formation upon steady-state photolysis of D6, D7 and D10.

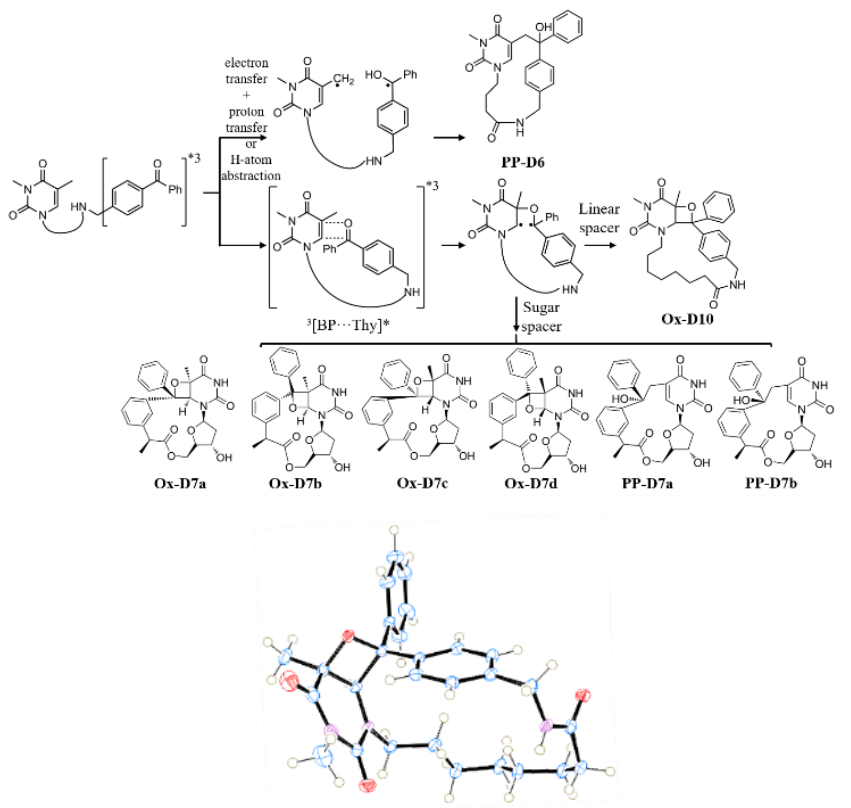

Figure 3. Structure of Ox-D10 in the crystalline state: $\mathrm{C}$ blue, $\mathrm{H}$ white, $\mathrm{O}$ red and $\mathrm{N}$ violet. Thermal ellipsoids are drawn at the $50 \%$ probability level.

In order to characterize the excited states involved in the photochemical reactivity of each dyad and to elucidate the mechanistic pathways leading to the isolated photoproducts, transient absorption experiments were performed on D4, D6 and D10, using BPN as a reference compound. Measurements in the femtosecond time scale were conducted upon excitation at $280 \mathrm{~nm}$ in $\mathrm{MeCN}$; control experiments demonstrated that, under the employed conditions, the degree of photodecomposition of the four compounds was lower than $5 \%$.
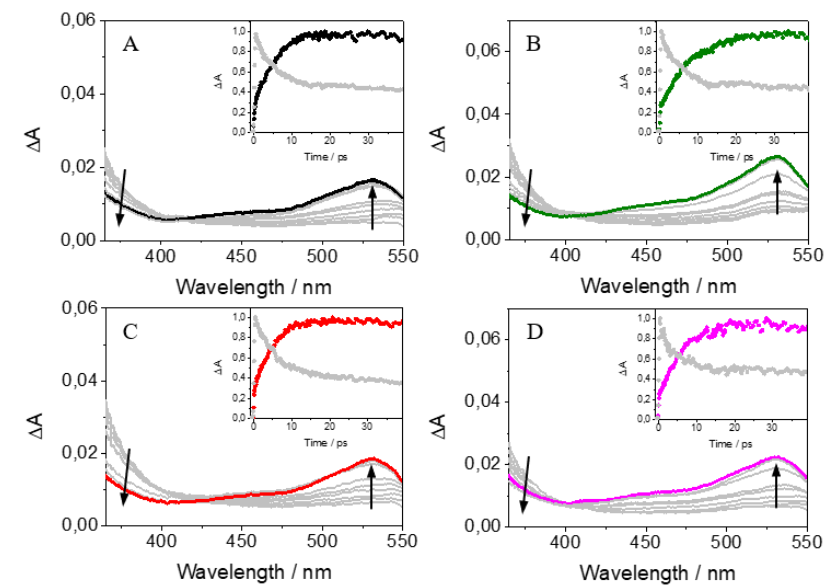
Figure 4. Femtosecond transient absorption spectra from 0.5 to 40 ps for BPN (A), D4 (B), D6 (C) and D10 (D) upon excitation at $280 \mathrm{~nm}$ in MeCN. The insets show the kinetic traces at $340 \mathrm{~nm}$ (gray) and $530 \mathrm{~nm}$ : BPN (black), D4 (red), D6 (green) and D10 (magenta)

As expected, the photobehavior of BPN at the really early times after excitation was very similar to that displayed by $\mathrm{BP},{ }^{28,36}$ but with different kinetics. Hence, the triplet excited state of BPN displayed a maximum at $c a .530 \mathrm{~nm}$; it was formed within ca. 5.5 ps through intersystem crossing (ISC) concomitantly with the disappearance of the band centered at $340 \mathrm{~nm}$, associated with the singlet-singlet absorption. Interestingly, a similar trend with analogous kinetics was detected for D4, D6 and D10 (see Figure 4). This suggests that the photoreactivity of all dyads occurs once the triplet excited state of the benzophenone chromophore has been completely formed. Therefore, nanosecond laser flash photolysis (LFP) experiments were performed upon excitation at $355 \mathrm{~nm}$ with the aim of investigating the transient species at longer times. Thus, photolysis of BPN gave rise to its triplet-triplet absorption band with maxima centered at $c a$. 320 and $530 \mathrm{~nm}$. A similar trend was observed for the dyads (see Figure S12 in the Supporting Information).
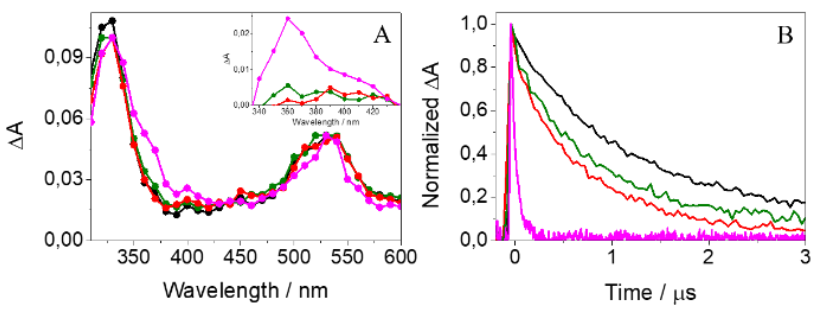

Figure 5. LFP spectra recorded at the very beginning after the laser pulse (A) and decay traces at $530 \mathrm{~nm}$ (B) for BPN (black), D4 (green), D6 (red) and D10 (magenta). The inset in (A) shows the transient absorption spectra obtained by subtraction of the ${ }^{3} \mathrm{BPN}^{*}$ spectrum from that of the corresponding dyad. All measurements were performed in deaerated $\mathrm{MeCN}$ at $\lambda_{\text {exc }}=355 \mathrm{~nm}$.

A more detailed analysis of the LFP spectra revealed marginal absorption between 350 and $420 \mathrm{~nm}$, only for D10. This band is difficult to visualize due to overlap with that of $320 \mathrm{~nm}$; however, it can be clearly observed by subtracting the ${ }^{3} \mathrm{BPN}^{*}$ spectrum from that of the corresponding dyad (inset in Figure 5A). The weak absorption band found for D10 displays a maximum at $\sim 360 \mathrm{~nm}$, analogous to that of ${ }^{3}$ Thy*. ${ }^{37}$ Indeed, a very similar band was previously detected for related Thy-benzophenone conjugates, and it was associated with the formation of ${ }^{3}$ Thy* by triplet-triplet energy transfer (TTET) from ${ }^{3} \mathrm{BP}^{*} .38$ Moreover, the involvement of triplet exciplexes arising from the photocleavage of oxetanes composed of BP and dimethylthymine (DMT) has been recently proposed. The signature of these exciplexes $\left.{ }^{3}[\mathrm{BP} \cdots \mathrm{DMT}]^{*}\right)$ is the appearance of an absorption band at ca. $400 \mathrm{~nm}$, whose formation depends on the oxetane regiochemistry. ${ }^{28}$ Therefore, by analogy, the weak absorption detected for D10 could also be associated with a triplet exciplex between the benzophenone and thymine units.

Interestingly, D10 is the only linear dyad that generates an oxetane upon absorption of UVA light. This must be related with the length of the spacer compared to D4 and D6, which may allow reaching the appropriate conformational arrangement between the two chromophores enabling closer interaction between the carbonyl group of BP and the $\mathrm{C} 5=\mathrm{C} 6$ double bond of Thy, thus favoring the formation of a triplet exciplex $\left({ }^{3}[\mathrm{BP} \cdots \text {...Thy }]^{*}\right)$. This species would later evolve towards the formation of the oxetane (see Scheme $3)$. In this context, the shorter interchromophoric distance in D4 and D6 might be associated with a higher strain to reach the proper conformational arrangement to form ${ }^{3}$ [BP...Thy ${ }^{*}$. Indeed, a significant degree of polymerization was observed for both dyads, although in the case of D6 the (sterically less demanding) hydrogen abstraction product PP-D6 was obtained in low yields.

Analysis of the triplet decay traces at $530 \mathrm{~nm}$ evidenced a clear intramolecular quenching for all dyads (see Figure 5B). This quenching was not associated to triplet-triplet annihilation since the results obtained at different laser intensities were very similar. The decays followed in all cases a first-order exponential law; the reference compound BPN showed a triplet lifetime of $1.5 \mu \mathrm{s}$, which was markedly shortened in D10 $(\sim 0,05 \mu \mathrm{s})$ in line with its highest photochemical reactivity. By contrast, $\mathbf{D} 4$ was the dyad with the longest lifetime, $c a$. $1.0 \mu \mathrm{s}$, which agrees well with its lowest reactivity. Accordingly, D6 exhibited an intermediate triplet lifetime $(\sim 0,8 \mu \mathrm{s})$, shorter than D4 but longer than D10, in line with its photoreactivity. Thus, a good correlation was found between the results obtained in the steady-state photolysis and the laser flash photolysis experiments.

The triplet lifetimes obtained by LFP for all dyads and for the reference compounds BPN and KP are summarized in Table 1, together with the intramolecular quenching rate constants $\left(\mathrm{k}_{\mathrm{Q}}\right)$, calculated by subtraction of the reciprocal lifetimes. Thus, the $\mathrm{k}_{\mathrm{Q}}$ values for the dyads were in the order of $10^{5}-10^{7} \mathrm{~s}^{-1}$, whereas the reported intermolecular photoreaction rate constant between ${ }^{3} \mathrm{BP}^{*}$ and DMT is $3.5 \times 10^{8} \mathrm{M}-$ ${ }^{1} \mathrm{~S}^{-1} .{ }^{39}$ Taking into account that the concentration of dyads employed in the product studies was in the order of $2.6 \mathrm{mM}$, the intermolecular reaction rates would be $c a .10^{6} \mathrm{~s}^{-1}$. Accordingly, polymerization competes with the intramolecular reaction for D4 and to a lesser extent for D6; conversely, the intramolecular process is much faster and prevails in the case of D10.

Table 1. Photophysical data (triplet lifetimes and intramolecular quenching rate constants) obtained for the investigated dyads and their reference compounds.

\begin{tabular}{|l|l|l|}
\hline & $\tau\left({ }^{3} \mathrm{BP}^{*}\right) / \mu \mathrm{s}$ & $\mathrm{k}_{\mathrm{Q}} / \mathrm{s}^{-1}$ \\
\hline BPN & 1.5 & - \\
\hline D4a & 1.0 & $3.3 \times 10^{5}$ \\
\hline D6 ${ }^{\mathrm{a}}$ & 0.8 & $5.8 \times 10^{5}$ \\
\hline D10a & 0.05 & $1.9 \times 10^{7}$ \\
\hline KP & 1.3 & - \\
\hline D7b & 0.03 & $3.3 \times 10^{7}$ \\
\hline $\begin{array}{l}\text { a determined as }\left(1 / \tau_{\text {dyad }}-1 / \tau_{\mathrm{BPN}}\right) ;{ }^{\mathrm{b}} \text { determined as }\left(1 / \tau_{\mathrm{D} 7}\right. \\
\left.-1 / \tau_{\mathrm{KP}}\right)\end{array}$
\end{tabular}


Having established that the photobehavior of the linear dyads is highly influenced by the distance between the BP and Thy moieties, the photophysical properties of D7 were reinvestigated. It has been reported that steady-state irradiation of $\mathbf{D 7}$ gives mainly rise to the formation of oxetanes, along with minor amounts of photoproducts arising from a formal intramolecular hydrogen abstraction process. ${ }^{33}$ Accordingly, a fast deactivation of the triplet excited state of KP was evidenced for D7, which was attributed to its high reactivity due to the strong intramolecular interaction between the KP and Thy units. In order to get a deeper insight into the photophysical properties of D7, femtosecond transient absorption measurements $\left(\lambda_{\text {exc }}=280 \mathrm{~nm}\right)$ were performed using KP as a reference. As expected, the triplet excited state of KP, with $\lambda_{\max }=530 \mathrm{~nm},{ }^{40-41}$ was formed within ca. 9.5 ps. The same was true for D7 (see Figure S13 in the Supporting Information), suggesting that its photoreactions occur once ${ }^{3} \mathrm{KP}^{*}$ is completely formed. Consequently, the photophysical properties of $\mathbf{D 7}$ were reinvestigated in longer timescales by means of LFP.
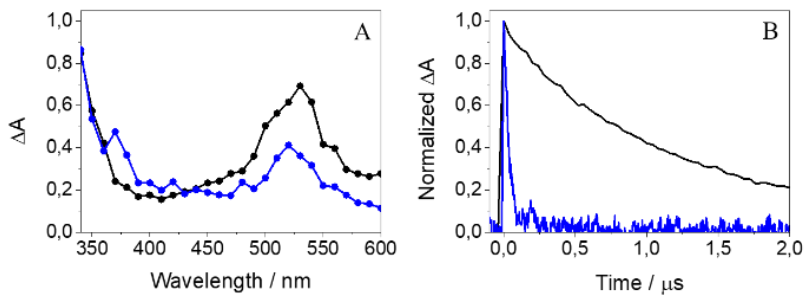

Figure 6. LFP spectra recorded at the very beginning after the laser pulse (A) and decay traces at $530 \mathrm{~nm}$ (B) for KP (black) and $\mathbf{D} 7$ (blue) after excitation at $355 \mathrm{~nm}$ in deaerated MeCN.

Excitation of D7 at $355 \mathrm{~nm}$ resulted in the formation of ${ }^{3} \mathrm{KP} *$ with maximum at $530 \mathrm{~nm}$ (see Figure 6). In agreement with a previous report, ${ }^{33}$ the triplet lifetime of KP in the dyad was strongly quenched ( $\sim 30 \mathrm{~ns}$ ) compared to the isolated chromophore $(1.3 \mu \mathrm{s})$, in line with its high photochemical reactivity. Interestingly, the transient absorption spectrum of D7 clearly showed a band with maximum $c a .370$ $\mathrm{nm}$, very similar to that observed for D10. Again, this band could be associated with a triplet exciplex between KP and Thy, which would evolve towards the formation of the oxetanes.

Overall, the photoreactivity of the investigated dyads has evidenced remarkable differences due to the interchromophoric distance between BP and Thy, and also to the conformational arrangement provided by the spacer.

\section{CONCLUSIONS}

The photobehavior of a series of dyads composed of benzophenone and thymine separated by spacers of different length has been investigated in the present work by means of steady-state photolysis and transient absorption spectroscopy. In general, the photoreactivity of the dyads can be satisfactorily correlated with their photophysical properties. Ultrafast spectroscopy reveals that, in all cases, the photochemical reactions occur once the triplet excited state of the BP chromophore has been fully populated after a few picoseconds. In this context, nanosecond laser flash photolysis demonstrates that D10 and D7 have the shortest triplet lifetimes, due to a faster intramolecular quenching, in line with their higher photoreactivity. Interestingly, a transient absorption band with maximum centered at $c a .370 \mathrm{~nm}$ is detected for both D10 and D7 upon laser flash photolysis, which can be attributed to the formation of a triplet exciplex that might finally evolve towards the formation of oxetanes. In conclusion, the obtained results suggest that not only the interchromophoric distance between benzophenone and thymine plays a significant role in the photobehavior of the investigated dyads, but also the conformational arrangement enhanced by the degree of flexibility of the spacer.

\section{EXPERIMENTAL SECTION}

Chemicals and reagents. Thymine (Thy) and 4-benzoylbenzylamine (BPN) hydrochloride were purchased from Achemblock. Ethyl 8-bromooctanoate was purchased from Fluorochem. Thymine-1-acetic acid, 1-ethyl-3-(3-dimethylaminopropyl)carbodiimide (EDC), ethyl 4-bromobutyrate, 1-hydroxybenzotriazole (HOBt), dimethyl sulphate, sodium carbonate and potassium carbonate were purchased from Sigma-Aldrich. Sodium hydroxide $(\mathrm{NaOH})$, hydrochloric acid solution ( $\mathrm{HCl})$, acetonitrile $(\mathrm{MeCN})$ spectroscopic grade, dimethylformamide (DMF), dichloromethane (DCM), methanol $(\mathrm{MeOH})$, ethyl acetate and magnesium sulphate anhydrous were purchased from Scharlab.

\section{Synthesis of the dyads.}

Synthesis of $N$-(4-benzoylbenzyl)-2-(5-methyl-2,4-dioxo3,4-dihydropyrimidin-1(2H)-yl)acetamide (Int-D4): to a solution of $74.5 \mathrm{mg}$ of thymine-1-acetic acid $(0.4 \mathrm{mmol})$ in MeCN, $100 \mathrm{mg}(0.4 \mathrm{mmol})$ of 4-benzoylbenzylamine hydrochloride (BPN) and $180 \mathrm{mg}$ of EDC ( $0.94 \mathrm{mmol})$ were added. The mixture was stirred at room temperature overnight. The organic solvent was removed under reduced pressure and the crude was purified by column chromatography $\left(\mathrm{SiO}_{2}, \mathrm{CH}_{2} \mathrm{Cl}_{2} / \mathrm{MeOH}, 95: 5\right)$. The intermediate Int- $D 4$ was obtained as a colorless solid (105 $\mathrm{mg}, 70 \%$ yield).

${ }^{1} \mathrm{H}$ NMR (400 MHz, $\left.\mathrm{CD}_{3} \mathrm{OD}\right) \delta$ 7.78-7.47 (m, 9H), $7.41(\mathrm{~s}$, $1 \mathrm{H}), 4.52(\mathrm{~s}, 2 \mathrm{H}), 4.48(\mathrm{~s}, 2 \mathrm{H}), 1.89(\mathrm{~s}, 3 \mathrm{H}) ;{ }^{13} \mathrm{C}\left\{{ }^{1} \mathrm{H}\right\} \mathrm{NMR}(100$ $\left.\mathrm{MHz}, \mathrm{CD}_{3} \mathrm{OD}\right) \delta 196.9,168.5,165.6,151.8,143.5,142.3$, $137.5,136.1,133.1,130.0,129.5,128.2,127.1,109.9,49.9$, 42.7, 10.9; HRMS (ESI): m/z calcd. for $\left(\mathrm{MH}^{+}\right) \mathrm{C}_{21} \mathrm{H}_{20} \mathrm{~N}_{3} \mathrm{O}_{4}$ : 378.1457, found: 378.1454 .

Synthesis of $N$-(4-benzoylbenzyl)-2-(3,5-dimethyl-2,4-dioxo-3,4-dihydropyrimidin-1(2H)-yl)acetamide (dyad D4): to a solution of Int-D4 (22.8 mg, $0.06 \mathrm{mmol})$ in $4 \mathrm{~mL}$ of $\mathrm{NaOH}$ $(2.5 \mathrm{M})$ in pure water, $30 \mu \mathrm{L}$ of dimethyl sulphate $(0.2$ mmol) were added dropwise. The mixture was stirred at room temperature overnight. The crude product was extracted with ethyl acetate, dried with anhydrous $\mathrm{MgSO}_{4}$, filtered and concentrated under reduced pressure. The final product D4 was obtained as a colorless solid (20 mg, 83\% yield).

${ }^{1} \mathrm{H}$ NMR (400 MHz, $\left.\mathrm{CD}_{3} \mathrm{OD}\right) \delta$ 7.76-7.47 (m, 9H), $7.43(\mathrm{~s}$, $1 \mathrm{H}), 4.52(\mathrm{~s}, 2 \mathrm{H}), 4.48(\mathrm{~s}, 2 \mathrm{H}), 2.16(\mathrm{~s}, 3 \mathrm{H}), 1.92(\mathrm{~s}, 3 \mathrm{H})$; ${ }^{13} \mathrm{C}\left\{{ }^{1} \mathrm{H}\right\}$ NMR $\left(100 \mathrm{MHz}, \mathrm{CD}_{3} \mathrm{OD}\right) \delta 196.9,168.4,164.7,151.9$, $143.5,140.4,137.5,136.3,132.4,130.0,129.5,128.1,127.0$, $108.9,50.9,42.5,26.9,11.5$; HRMS (ESI): $m / z$ calcd. for $\left(\mathrm{MH}^{+}\right) \mathrm{C}_{22} \mathrm{H}_{22} \mathrm{~N}_{3} \mathrm{O}_{4}$ : 392.1610, found: 392.1613 .

The synthesis of the intermediate Thy-1 has been explained elsewhere. ${ }^{42}$ Briefly, to a solution of $6.35 \mathrm{~g}$ (50 mmol) of thymine in $100 \mathrm{~mL}$ of dimethyl formamide (DMF), $15.5 \mathrm{~g}$ of $\mathrm{Na}_{2} \mathrm{CO}_{3}$ were added. Then, $8.6 \mathrm{~mL}(70 \mathrm{mmol})$ of ethyl 4-bromobutyrate were added and left stirring at 
$125^{\circ} \mathrm{C}$ using a reaction block for $6 \mathrm{~h}$. After this time, the crude was cooled down to room temperature and left stirring for 2 days. DMF was removed under reduced pressure and, after addition of $50 \mathrm{~mL}$ of water, the unreacted thymine precipitated, which was removed by filtration. The dissolved product was extracted with dichloromethane, washed with brine $(\times 2)$ and dried with $\mathrm{MgSO}_{4}$. The solvent was removed under reduced pressure and the residue was subsequently dissolved in $100 \mathrm{~mL}$ of $\mathrm{NaOH} 2 \mathrm{M}$ and stirred under reflux for 2 hours. Then, the solution was acidified with $\mathrm{HCl} 4 \mathrm{M}$ to $\mathrm{pH} 1$ and the final product was purified by recrystallization. The intermediate Thy-1 was obtained as a white solid ( $4.8 \mathrm{~g}, 45 \%$ yield).

Synthesis of $N$-(4-benzoylbenzyl)-4-(5-methyl-2,4-dioxo3,4-dihydropyrimidin-1(2H)-yl)butanamide (Int-D6): to a solution containing $1.7 \mathrm{~g}$ of thymine-1-butanoic acid (8.0 mmol), $2.1 \mathrm{~g}$ of EDC (11.0 mmol) and $1.18 \mathrm{~g}$ hydroxy benzotriazole (HOBt, $8.7 \mathrm{mmol}$ ) in anhydrous DMF, a solution of $1.8 \mathrm{~g}$ of BPN (7.3 mmol) in DMF was added dropwise. The mixture was stirred for 2 hours at $0^{\circ} \mathrm{C}$ using an ice bath. The DMF was removed under reduced pressure, and the crude was dissolved in dichloromethane and washed with $\mathrm{Na}$ $\mathrm{HCO}_{3} 1 \mathrm{M}(\times 3), \mathrm{HCl} 1 \mathrm{M}(\times 3)$ and brine $(\times 3)$. The final product Int-D6 was purified by recrystallization with methanol as a white solid (1.86 g, 60\% yield).

${ }^{1} \mathrm{H}$ NMR (400 MHz, $\left.\mathrm{CD}_{3} \mathrm{OD}\right) \delta$ 7.78-7.45 (m, 9H), $7.41(\mathrm{~s}$, $1 \mathrm{H}), 4.46(\mathrm{~s}, 2 \mathrm{H}), 3.78(\mathrm{t}, J=7.2 \mathrm{~Hz}, 2 \mathrm{H}), 2.33(\mathrm{t}, J=7.2 \mathrm{~Hz}$, 2H), $2.05(\mathrm{~m}, 2 \mathrm{H}), 1.87(\mathrm{~s}, 3 \mathrm{H}) ;{ }^{13} \mathrm{C}\left\{{ }^{1} \mathrm{H}\right\}$ NMR $(100 \mathrm{MHz}$, DMSO-d6) $\delta 195.4,171.4,164.3,150.9,144.7,141.4,137.1$, 135.5, 132.6, 129.8, 129.5, 128.5, 127.1, 108.4, 46.8, 41.8, 32.1, 24.6, 11.9; HRMS (ESI): $m / z$ calcd. for $\left(\mathrm{MH}^{+}\right)$ $\mathrm{C}_{23} \mathrm{H}_{24} \mathrm{~N}_{3} \mathrm{O}_{4}$ : 406.1760, found: 406.1764 .

Synthesis of $N$-(4-benzoylbenzyl)-4-(3,5-dimethyl-2,4-dioxo-3,4-dihydropyrimidin-1(2H)-yl)butanamide (dyad D6): to a solution of $135 \mathrm{mg}$ of Int-D6 (0.3 mmol) in $4 \mathrm{~mL}$ of $\mathrm{NaOH}(2.5 \mathrm{M}), 100 \mu \mathrm{L}$ of $\mathrm{SO}_{2}(\mathrm{OMe})_{2}(1 \mathrm{mmol})$ were added dropwise. The mixture was stirred overnight at room temperature. The crude product was extracted with ethyl acetate $(\times 3)$, washed with $1 \mathrm{M} \mathrm{NaHCO} 3$ and dried with anhydrous $\mathrm{MgSO}_{4}$, filtered and concentrated under reduced pressure. The final product was purified by precipitation in dichoromethane/hexane to get D6 as a white solid (118 mg, $85 \%$ yield).

${ }^{1} \mathrm{H}$ NMR (400 MHz, CD $\left.{ }_{3} \mathrm{OD}\right) \delta$ 7.75-7.44 (m, 9H), $7.42(\mathrm{~s}$, $1 \mathrm{H}), 4.45(\mathrm{~s}, 2 \mathrm{H}), 3.81(\mathrm{t}, J=7.2 \mathrm{~Hz}, 2 \mathrm{H}), 3.29(\mathrm{~s}, 3 \mathrm{H}), 2.32(\mathrm{t}$, $J=7.2 \mathrm{~Hz}, 2 \mathrm{H}), 2.02(\mathrm{~m}, 2 \mathrm{H}), 1.89(\mathrm{~s}, 3 \mathrm{H}) ;{ }^{13} \mathrm{C}\left\{{ }^{1} \mathrm{H}\right\} \mathrm{NMR}(100$ $\left.\mathrm{MHz}, \mathrm{CD}_{3} \mathrm{OD}\right) \delta 196.8,173.4,164.6,151.8,143.9,139.8$, $137.5,136.3,132.4,130.0,129.5,128.1,127.1,108.9,48.5$, 42.4, 32.1, 26.9, 24.6, 11.5; Yield: 85\%. HRMS (ESI): $m / z$ calcd. for $\left(\mathrm{MH}^{+}\right) \mathrm{C}_{24} \mathrm{H}_{26} \mathrm{~N}_{3} \mathrm{O}_{4}: 420.1923$, found: 420.1927 .

Synthesis of 8-(5-methyl-2,4-dioxo-3,4-dihydropyrimidin-1(2H)-yl)octanoic acid (Thy-2): to a solution of $6.35 \mathrm{~g}$ of thymine ( $50 \mathrm{mmol})$ in DMF $(100 \mathrm{~mL}), 7.5 \mathrm{~g}$ of $\mathrm{Na}_{2} \mathrm{CO}_{3}(50$ $\mathrm{mmol}$ ) and $14.8 \mathrm{~mL}$ of ethyl 8-bromooctanoate (70 mmol) were added. The temperature was risen using a reaction block until the solution was clear, and the mixture was stirred for $6 \mathrm{~h}$. Then, it was cooled down and left stirring for 2 days at room temperature. The DMF was removed under reduced pressure, and the crude was dissolved in water (50 $\mathrm{mL})$. The product was extracted with dichloromethane, washed with brine $(\times 3)$ and dried with anhydrous $\mathrm{MgSO}_{4}$.
The solvent was removed under reduced pressure and subsequently dissolved in $50 \mathrm{~mL}$ of $\mathrm{NaOH}(2.5 \mathrm{M})$ and stirred under reflux, using a reaction block, for 2 hours. Then, the mixture was cooled down to room temperature. The solution was acidified with $\mathrm{HCl}(4 \mathrm{M})$ to $\mathrm{pH} 1$, and the precipitate was purified by silica gel chromatography using a mixture of ethyl acetate/methanol/acetic acid (8:2:0.1). The intermediate Thy-2 was obtained as a white solid (10 g, $75 \%$ yield).

${ }^{1} \mathrm{H}$ NMR (400 MHz, CD $\left.{ }_{3} \mathrm{OD}\right) \delta 7.44(\mathrm{~s}, 1 \mathrm{H}), 3.71(\mathrm{t}, J=7.6$ $\mathrm{Hz}, 2 \mathrm{H}), 2.22(\mathrm{t}, J=7.6 \mathrm{~Hz}, 2 \mathrm{H}), 1.87(\mathrm{~s}, 3 \mathrm{H}), 1.67-1.60(\mathrm{~m}$, $4 \mathrm{H}), 1.36(\mathrm{~m}, 6 \mathrm{H}) ;{ }^{13} \mathrm{C}\left\{{ }^{1} \mathrm{H}\right\}$ NMR (100 MHz, CD $\left.{ }_{3} \mathrm{OD}\right) \delta 176.1$, 166.6, 151.6, 141.9, 109.7, 48.0, 34.7, 28.8, 28.5, 25.9, 25.0, 20.7, 10.8; HRMS (ESI): $m / z$ calcd. for $\left(\mathrm{MH}^{+}\right) \mathrm{C}_{13} \mathrm{H}_{21} \mathrm{~N}_{2} \mathrm{O}_{4}$ : 269.1512, found: 269.1501 .

Synthesis of $N$-(4-benzoylbenzyl)-8-(5-methyl-2,4-dioxo3,4-dihydropyrimidin-1(2H)-yl)octanamide (Int-D10): to a solution of Thy-2 $(0.73 \mathrm{~g}, 2.7 \mathrm{mmol})$ in DMF, $0.78 \mathrm{~g}$ of EDC ( $4.1 \mathrm{mmol}$ ) and $0.44 \mathrm{~g}$ of HOBt $(3.3 \mathrm{mmol})$ were added; the mixture was kept at $0{ }^{\circ} \mathrm{C}$ using an ice bath for $15 \mathrm{~min}$. Then, a solution of BPN $(0.74 \mathrm{~g}, 3.0 \mathrm{mmol})$ in DMF was added dropwise. The mixture was stirred at $0{ }^{\circ} \mathrm{C}$ for 2 hours. Then, DMF was removed under reduced pressure and the crude was dissolved in ethyl acetate and washed with $1 \mathrm{M} \mathrm{NaHCO}_{3}$, $\mathrm{HCl} 1 \mathrm{M}$ and brine. The final product Int-D10 was purified by recrystallization and obtained as a white solid (563 mg, $45 \%$ yield).

${ }^{1} \mathrm{H}$ NMR (400 MHz, $\left.\mathrm{CD}_{3} \mathrm{OD}\right) \delta$ 7.76-7.43 (m, 9H), $7.41(\mathrm{~s}$, $1 \mathrm{H}), 4.46(\mathrm{~s}, 2 \mathrm{H}), 3.69(\mathrm{t}, J=7.2 \mathrm{~Hz}, 2 \mathrm{H}), 2.27(\mathrm{t}, J=7.2 \mathrm{~Hz}$, 2H), $1.86(\mathrm{~s}, 3 \mathrm{H}), 1.65(\mathrm{~m}, 4 \mathrm{H}), 1.36(\mathrm{~m}, 6 \mathrm{H}) ;{ }^{13} \mathrm{C}\left\{{ }^{1} \mathrm{H}\right\} \mathrm{NMR}$ $\left(100 \mathrm{MHz}, \mathrm{CD}_{3} \mathrm{OD}\right) \delta 196.9,174.9,165.5,151.5,144.2,141.8$, 137.5, 136.2, 132.4, 130.0, 129.6, 128.1, 127.1, 109.7, 47.9, 42.3 , 35.6, 28.7, 28.5, 28.5, 25.9, 25.4, 10.8; HRMS (ESI): $m / z$ calcd. for $\left(\mathrm{MH}^{+}\right) \mathrm{C}_{27} \mathrm{H}_{32} \mathrm{~N}_{3} \mathrm{O}_{4}$ : 462.2393, found: 462.2398 .

Synthesis of $N$-(4-benzoylbenzyl)-8-(3,5-dimethyl-2,4-dioxo-3,4-dihydropyrimidin-1(2H)-yl)octanamide (dyad D10): to a solution of Int-D10 (260 $\mathrm{mg}, 0.56 \mathrm{mmol})$ in $3 \mathrm{~mL}$ of $\mathrm{NaOH}(2.5 \mathrm{M}), 250 \mu \mathrm{L}$ of $\mathrm{SO}_{2}(\mathrm{OMe})_{2}(2.5 \mathrm{mmol})$ were added dropwise. The mixture was stirred overnight at room temperature. The crude product was extracted with ethyl acetate $(\times 3)$, washed with $1 \mathrm{M} \mathrm{NaHCO}_{3}$ and dried with anhydrous $\mathrm{MgSO}_{4}$, filtered and concentrated under reduced pressure. The final product was purified by precipitation in dichloromethane/hexane to get D10 as a white solid (236 $\mathrm{mg}, 89 \%$ yield).

${ }^{1} \mathrm{H}$ NMR (400 MHz, $\left.\mathrm{CDCl}_{3}\right) \delta$ 7.75-7.44 (m, 9H), $6.96(\mathrm{~s}$, $1 \mathrm{H}), 4.52(\mathrm{~s}, 2 \mathrm{H}), 3.69(\mathrm{t}, J=7.2 \mathrm{~Hz}, 2 \mathrm{H}), 3.34(\mathrm{~s}, 3 \mathrm{H}), 2.25(\mathrm{t}$, $J=7.2 \mathrm{~Hz}, 2 \mathrm{H}), 1.93(\mathrm{~s}, 3 \mathrm{H}), 1.68(\mathrm{~m}, 4 \mathrm{H}), 1.35(\mathrm{~m}, 6 \mathrm{H})$; ${ }^{13} \mathrm{C}\left\{{ }^{1} \mathrm{H}\right\} \mathrm{NMR}\left(100 \mathrm{MHz}, \mathrm{CD}_{3} \mathrm{OD}\right) \delta 196.8,174.9,164.6,151.7$, $144.1,139.9,137.5,136.2,132.4,130.0,129.6,128.1,127.1$, 112.2, 49.1, 42.4, 35.6, 28.6, 28.5, 28.4, 26.9, 25.9, 25.4, 11.5; Yield: $89 \%$. HRMS (ESI): $m / z$ calcd. for $\left(\mathrm{MH}^{+}\right) \mathrm{C}_{28} \mathrm{H}_{34} \mathrm{~N}_{3} \mathrm{O}_{4}$ : 476.2549, found: 476.2546 .

(Z)-3-hydroxy-13-methyl-3-phenyl-1 $1^{1}, 1^{2}, 1^{3}, 1^{4}$-tetrahydro-6-aza-1(5,1)-pyrimidina-4(1,4)-benzenacyclodecaphane-12,14,7-trione (PP-D6). ${ }^{1} \mathrm{H}$ NMR (400 MHz, CD $\left.{ }_{3} \mathrm{OD}\right) \delta$ 7.64-7.26 (m, 9H), $6.91(\mathrm{~m}, 1 \mathrm{H}), 5.43(\mathrm{~s}, 1 \mathrm{H}), 4.32$ (d, J = 13.6 $\mathrm{Hz}, 1 \mathrm{H}), 4.03$ (d, $J=13.6 \mathrm{~Hz}, 1 \mathrm{H}), 3.70(\mathrm{~m}, 1 \mathrm{H}), 3.55$ (d, $J=$ $13.6 \mathrm{~Hz}, 1 \mathrm{H}), 3.27(\mathrm{~s}, 3 \mathrm{H}), 3.14(\mathrm{~m}, 1 \mathrm{H}), 3.03(\mathrm{~d}, J=13.6 \mathrm{~Hz}$, $1 \mathrm{H}), 2.23(\mathrm{~m}, 1 \mathrm{H}), 1.84(\mathrm{~m}, 1 \mathrm{H}), 1.70(\mathrm{~m}, 1 \mathrm{H}), 1.15(\mathrm{~m}, 1 \mathrm{H})$; 
${ }^{13} \mathrm{C}\left\{{ }^{1} \mathrm{H}\right\}$ NMR $\left(100 \mathrm{MHz}, \mathrm{CD}_{3} \mathrm{OD}\right) \delta 174.7,165.5,151.2,147.1$, $145.0,142.4,138.5,128.9,127.8,127.3,126.9,126.9,126.5$, 126.4, 108.1, 78.5, 48.7, 43.1, 38.0, 32.5, 27.0, 25.9; HRMS (ESI): $m / z$ calcd. for $\left(\mathrm{MH}^{+}\right) \mathrm{C}_{24} \mathrm{H}_{26} \mathrm{~N}_{3} \mathrm{O}_{4}: 420.1923$, found: 420.1927.

$1^{4}, 1^{6}$-dimethyl-18 ${ }^{8}$-phenyl-17-oxa- $1^{2}, 1^{4}, 4$-triaza- $1(8,2)$-bicyclo[4.2.0] octana-2(1,4)-benzenacyclododecaphane-

$1^{3}, 1^{5}, 5$-trione (Ox-D10). ${ }^{1} \mathrm{H}$ NMR $\left(400 \mathrm{MHz}, \mathrm{CDCl}_{3}\right) \delta 7.50$ $7.08(\mathrm{~m}, 9 \mathrm{H}), 5.91(\mathrm{~m}, 1 \mathrm{H}), 4.90\left(\mathrm{dd}, J_{1}=8.8 \mathrm{~Hz}, J_{2}=14 \mathrm{~Hz}\right.$, $1 \mathrm{H}), 4.52(\mathrm{~s}, 1 \mathrm{H}), 3.80\left(\mathrm{dd}, J_{1}=4 \mathrm{~Hz}, J_{2}=14 \mathrm{~Hz}, 1 \mathrm{H}\right), 3.57(\mathrm{~m}$, $1 \mathrm{H}), 3.34(\mathrm{~s}, 3 \mathrm{H}), 2.49(\mathrm{~m}, 1 \mathrm{H}), 2.24(\mathrm{~m}, 1 \mathrm{H}), 2.00(\mathrm{~m}, 1 \mathrm{H})$, $1.62(\mathrm{~s}, 3 \mathrm{H}), 1.8-0.2(\mathrm{~m}, 10 \mathrm{H}) ;{ }^{13} \mathrm{C}\left\{{ }^{1} \mathrm{H}\right\}$ NMR $(100 \mathrm{MHz}$, $\left.\mathrm{CDCl}_{3}\right) \delta 172.9,168.6,151.7,143.7,140.5,138.6,128.7$, 128.5, 128.4, 128.0, 126.0, 90.7, 75.1, 69.0, 51.7, 42.7, 36.4, 28.6, 27.9, 27.3, 26.7, 26.6, 26.3, 24.4; HRMS (ESI): $m / z$ calcd. for $\left(\mathrm{MH}^{+}\right) \mathrm{C}_{28} \mathrm{H}_{34} \mathrm{~N}_{3} \mathrm{O}_{4}: 476.2549$, found: 476.2545 . CCDC 2022525.

Steady-state photolysis. Irradiations were performed in a multilamp Luzchem photoreactor emitting at $\lambda_{\max }=350$ $\mathrm{nm}(14 \times 8 \mathrm{~W}$ lamps). Isoabsorptive solutions at $350 \mathrm{~nm}$ (A $=0.05$, concentration $\sim 20 \mu \mathrm{M}$ ) of the different bichromophoric systems were irradiated at different times in acetonitrile under $\mathrm{N}_{2}$ through quartz cells. For photoproduct studies, higher concentrations of the dyads $(2.6 \mathrm{mM})$ were used; irradiations were performed through Pyrex for $3 \mathrm{~h}$.

Analytical instrumentation. A semipreparative JASCO HPLC system (PU-2080 Plus pump, DG-2080-54 line degasser and LG-2080-04 gradient unit) connected to a JASCO (UV-1575) detector was used to separate and purify the different photoproducts, using an isocratic flux ( $2 \mathrm{~mL} / \mathrm{min})$ of MeCN as an eluent, and a SEA18 Teknokroma column, $5 \mu \mathrm{m}$ $(25 \mathrm{~cm} \times 1 \mathrm{~cm})$.

Spectroscopic Techniques. The ${ }^{1} \mathrm{H}$ and ${ }^{13} \mathrm{C}$ NMR spectra were recorded at 400 and $100 \mathrm{MHz}$, respectively, using a Bruker AVANCE III instrument; chemical shifts are reported in ppm.

High-resolution mass spectrometry (HRMS) was performed in an Ultra Performance Liquid Chromatography (UPLC) ACQUITY system (Waters Corp.) with a conditioned autosampler at $4{ }^{\circ} \mathrm{C}$. The separation was accomplished on an ACQUITY UPLC BEH C18 column $(50 \mathrm{~mm} \times 2.1 \mathrm{~mm}$ i.d., $1.7 \mu \mathrm{m})$, which was maintained at $40^{\circ} \mathrm{C}$. The analysis was performed using acetonitrile and water $(60: 40 \mathrm{v} / \mathrm{v}$ containing $0.01 \%$ formic acid) as the mobile phase with a flow rate of $0.5 \mathrm{~mL} / \mathrm{min}$, and injection volume was $5 \mu \mathrm{L}$. The Waters ACQUITY $^{\text {м }}$ XevoQToF Spectrometer (Waters Corp.) was connected to the UPLC system via an electrospray ionization (ESI) interface. This source was operated in positive ionization mode with the capillary voltage at $1.5 \mathrm{kV}$ at 100 ${ }^{\circ} \mathrm{C}$ and the temperature of the desolvation was $300{ }^{\circ} \mathrm{C}$. The cone and desolvation gas flows were $40 \mathrm{~L} \mathrm{~h}^{-1}$ and $800 \mathrm{~L} \mathrm{~h}^{-1}$, respectively. The collision gas flow and collision energy applied were $0.2 \mathrm{~mL} / \mathrm{min}$ and $12 \mathrm{~V}$, respectively. All data collected in Centroid mode were acquired using Masslyn $x^{\mathrm{TM}}$ software (Waters Corp.). Leucine-enkephalin was used at a concentration of $500 \mathrm{pg} / \mu \mathrm{L}$ as the lock mass generating an $[\mathrm{M}+\mathrm{H}]^{+}$ion $(\mathrm{m} / z$ 556.2771) and fragment at $m / z 120.0813$ and flow rate of $50 \mu \mathrm{L} / \mathrm{min}$ to ensure accuracy during the MS analysis.
Steady-state absorption spectra were recorded in a JASCO V-760 spectrophotometer. Laser Flash Photolysis (LFP) measurements were performed using a pulsed Nd:YAG L52137 V LOTIS TII at the excitation wavelength of $355 \mathrm{~nm}$. The single pulses were $c a .10$ ns duration, and the energy was $\sim 12 \mathrm{~mJ} /$ pulse. The laser flash photolysis system consisted of the pulsed laser, a 77250 Oriel monochromator and an oscilloscope DP04054 Tektronix. The output signal from the oscilloscope was transferred to a personal computer. Absorbances of all solutions were adjusted at $\sim 0.20$ at $355 \mathrm{~nm}$ in MeCN. All UV and LFP measurements were done using $10 \times 10 \mathrm{~mm}^{2}$ quartz cuvettes at room temperature in deaerated conditions ( $25 \mathrm{~min}_{2}$ bubbling), using 30 $\mathrm{mL}$ of fresh solution in order to avoid data acquisition from photodegraded products.

Femtosecond transient absorption experiments were performed using a pump-probe system. The femtosecond pulses were generated with a mode-locked Ti-Sapphire laser of a compact Libra HE ( $4 \mathrm{~W}$ power at $4 \mathrm{kHz}$ ) regenerative amplifier delivering $100 \mathrm{fs}$ pulses at $800 \mathrm{~nm} \mathrm{(1}$ $\mathrm{mJ} /$ pulse). The output of the laser was split into two parts to generate the pump and the probe beams. Thus, tunable femtosecond pump pulses were obtained by directing the $800 \mathrm{~nm}$ light into an optical parametric amplifier. In the present case, the pump was set at $280 \mathrm{~nm}$ and passed through a chopper prior to focus onto a rotating cell $(1 \mathrm{~mm}$ optical path) containing the samples in organic solution. The white light used as probe was produced after part of the $800 \mathrm{~nm}$ light from the amplifier travelled through a computer controlled 8 ns variable optical delay line and impinge on a $\mathrm{CaF}_{2}$ rotating crystal. This white light was in turn split in two identical portions to generate reference and probe beams that then are focused on the rotating cell containing the sample. The pump and the probe beams were made to coincide to interrogate the sample. The power of the pump beam was set to $180 \mu \mathrm{W}$. A computer-controlled imaging spectrometer was placed after this path to measure the probe and the reference pulses to obtain the transient absorption decays/spectra. The experimental data were treated and compensated by the chirp using the ExciPro program.

\section{ASSOCIATED CONTENT}

Supporting Information. ${ }^{1} \mathrm{H}$ and ${ }^{13} \mathrm{C}$ NMR spectra of the synthesized dyads and intermediates. UV, femtosecond transient absorption and laser flash photolysis spectra and kinetics. XRay crystallography data for Ox-D10.

\section{AUTHOR INFORMATION}

\section{Corresponding Authors}

Miguel A. Miranda - Departamento de Química/Instituto de Tecnología Química UPV-CSIC, Universitat Politècnica de València, Camino de Vera s/n, 46022 València (Spain); orcid.org/0000-0002-7717-8750; Email: mmiranda@qim.upv.es

Ignacio Vayá - Departamento de Química/Instituto de Tecnología Química UPV-CSIC, Universitat Politècnica de València, Camino de Vera s/n, 46022 València (Spain); orcid.org/00000003-1682-9342; Email: igvapre@qim.upv.es

Authors 
Alejandro Blasco-Brusola - Departamento de Química/Instituto de Tecnología Química UPV-CSIC, Universitat Politècnica de València, Camino de Vera s/n, 46022 València (Spain)

\section{Author Contributions}

The manuscript was written through contributions of all authors. / All authors have given approval to the final version of the manuscript.

\section{Funding Sources}

Ministerio de Economia y Competitividad and Consellería d’Educació, Investigació, Cultura i Esport.

Notes

The authors declare no competing financial interests.

\section{ACKNOWLEDGMENT}

Financial support from the Spanish Government (RYC-201517737 and CTQ2017-89416-R) and from the Consellería d'Educació Cultura i Esport (PROMETEO/2017/075 and GRISOLIAP/2017/005) is gratefully acknowledged. The authors would like to thank the use of RIAIDT-USC analytical facilities for the X-ray crystallography analysis.

\section{ABBREVIATIONS}

(6-4)PPs, pyrimidine (6-4) pyrimidone photoproducts; BP, benzophenone; BPN, 4-benzoylbenzylamine; CPD, cyclobutane pyrimidine dimers; DMT, dimethylthymine; ISC, intersystem crossing; KP, ketoprofen; LFP, laser flash photolysis; NSAIDs, non-steroidal anti-inflammatory drugs; $\mathrm{PB}$, Paternò-Büchi; PS, photosensitizer; Thy, thymine; TTET, triplet-triplet energy transfer.

\section{REFERENCES}

1. Friedel, M. G.; Cichon, M. K.; Carell, T., DNA damage and repair: photochemistry. 2nd ed.; CRC Handbook of Organic Photochemistry and Photobiology CRC Press LLC: Boca Raton, 2004.

2. Kraemer, K. H., Sunlight and skin cancer: another link revealed. Proc. Natl. Acad. Sci. USA 1997, 94, 11-14.

3. Cadet, J.; Mouret, S.; Ravanat, J. L.; Douki, T., Photoinduced damage to cellular DNA: direct and photosensitized reactions. Photochem. Photobiol. 2012, 88, 1048-1065.

4. Rastogi, R. P.; Richa; Kumar, A.; Tyagi, M. B.; Sinha, R. P., Molecular mechanisms of ultraviolet radiation-induced DNA damage and repair. J. Nucleic Acids 2010, 2010, 592980.

5. Sinha, R. P.; Hader, D. P., UV-induced DNA damage and repair: a review. Photochem. Photobiol. Sci. 2002, 1, 225-236.

6. Chatterjee, N.; Walker, G. C., Mechanisms of DNA damage, repair, and mutagenesis. Environ. Mol. Mutagen. 2017, 58 (5), 235263.

7. Brash, D. E.; Haseltine, W. A., UV-induced mutation hotspots occur at DNA damage hotspots. Nature 1982, 298, 189192.

8. $\quad$ Cadet, J.; Berger, M.; Douki, T.; Ravanat, J. L., Oxidative damage to DNA: formation, measurement, and biological significance. In Physiology biochemistry and pharmacology, Giessen, E. H., Ed. Springer: 1997; Vol. 131, pp 1-87.

9. Taylor, J.-S.; Cohrs, M. P., DNA, light and Dewar pyrimidones: the structure and biological significance of TpT3. J. Am. Chem. Soc. 1987, 109, 2834-2835.

10. Taylor, J.-S.; Garrett, D. S.; Cohrs, M. P., Solution-state structure of the Dewar pyrimidone photoproduct of thymidylyl(3'-5')-thymidine. Biochemistry 1988, 27, 7206-7215.

11. Kim, S.-T.; Malhotra, K.; Smith, C. A.; Taylor, J.-S.; Sancar, A., Characterization of (6-4) Photoproduct DNA Photolyase. J. Biol. Chem. 1994, 269, 8535-8540.
12. Li, J.; Liu, Z.; Tan, C.; Guo, X.; Wang, L.; Sancar, A.; Zhong, D., Dynamics and mechanism of repair of ultraviolet-induced (6-4) photoproduct by photolyase. Nature 2010, 466, 887-890.

13. Todo, T.; Ryo, H.; Yamamoto, K.; Toh, H.; Inui, T.; Ayaki, H.; Nomura, T.; lkenaga, M., Similarity Among the Drosophila (64) Photolyase, a Human Photolyase Homolog, and the DNA Photolyase-Blue-Light Photoreceptor Family. Science 1996, 272, 109112.

14. Todo, T.; Takemori, H.; Ryo, H.; Ihara, M.; Matsunaga, T.; Nikaido, O.; Sato, K.; Nomura, T., A new photoreactivating enzyme that specifically repairs ultraviolet light-induced (6-4)photoproducts. Nature 1993, 361, 371-374.

15. Todo, T.; Tsuji, H.; Otoshi, E.; Hitomi, K.; Kim, S.-T.; Ikenaga, M., Characterization of a human homolog of 6-4 photolyase. Mutat. Res. 1997, 384, 195-204.

16. Epe, B.; Pflaum, M.; Boiteux, S., DNA damage induced by photosensitizers in cellular and cell-free systems. Mutat. Res. 1993, 299, 135-145.

17. Michaud, S.; Hajj, V.; Latapie, L.; Noirot, A.; Sartor, V.; Fabre, P. L.; Chouini-Lalanne, N., Correlations between electrochemical behaviors and DNA photooxidative properties of non-steroidal anti-inflammatory drugs and their photoproducts. J. Photochem. Photobiol. B 2012, 110, 34-42.

18. Maguery, M. C.; Chouini-Lalanne, N.; Ader, J. C.; Paillous, N., Comparison of the DNA damage photoinduced by fenofibrate and ketoprofen, two phototoxic drugs of parent structure. Photochem. Photobiol. 1998, 68, 679-684.

19. Vinette, A. L.; McNamee, J. P.; Bellier, P. V.; McLean, J. R. N.; Scaiano, J. C., Prompt and Delayed Nonsteroidal Anti-inflammatory Drug-photoinduced DNA Damage in Peripheral Blood Mononuclear Cells Measured with the Comet Assay. Photochem. Photobiol. 2003, 77, 390-396.

20. Lhiaubet, V.; Gutierrez, F.; Penaud-Berruyer, F.; Amouyal, E.; Daudey, J.-P.; Poteau, R.; Chouini-Lalanne, N.; Paillous, N., Spectroscopic and theoretical studies of the excited states of fenofibric acid and ketoprofen in relation with their photosensitizing properties. New J. Chem. 2000, 24 (6), 403-410.

21. Lhiaubet, V.; Paillous, N.; Chouini-Lalanne, N., Comparison of DNA Damage Photoinduced by Ketoprofen, Fenofibric Acid and Benzophenone via Electron and Energy Transfer. Photochem. Photobiol. 2001, 74, 670-678.

22. Cuquerella, M. C.; Lhiaubet-Vallet, V.; Cadet, J.; Miranda, M. A., Benzophenone Photosensitized DNA Damage. Acc. Chem. Res. 2012, 45, 1558-1570.

23. Bignon, E.; Marazzi, M.; Besancenot, V.; Gattuso, H.; Drouot, G.; Morell, C.; Eriksson, L. A.; Grandemange, S.; Dumont, E.; Monari, A., Ibuprofen and ketoprofen potentiate UVA-induced cell death by a photosensitization process. Sci. Rep. 2017, 7 (1), 8885.

24. Bosca, F.; Miranda, M. A., Photosensitizing drugs containing the benzophenone chromophore. J. Photochem. Photobiol. B 1998, 43, 1-26.

25. Rogers, J. E.; Kelly, L. A., Nucleic Acid Oxidation Mediated by Naphthalene and Benzophenone Imide and Diimide Derivatives: Consequences for DNA Redox Chemistry. J. Am. Chem. Soc. 1999, 121, 3854-3861.

26. Surana, K.; Chaudhary, B.; Diwaker, M.; Sharma, S., Benzophenone: a ubiquitous scaffold in medicinal chemistry. Med. Chem. Commun. 2018, 9, 1803-1817.

27. Cuquerella, M. C.; Lhiaubet-Vallet, V.; Bosca, F.; Miranda, M. A., Photosensitised pyrimidine dimerisation in DNA. Chem. Sci. 2011, 2 (7), 1219-1232.

28. Blasco-Brusola, A.; Navarrete-Miguel, M.; Giussani, A.; Roca-Sanjuán, D.; Vayá, I.; Miranda, M. A., Regiochemical memory in the adiabatic photolysis of thymine-derived oxetanes. A combined ultrafast spectroscopic and CASSCF/CASPT2 computational study. Phys. Chem. Chem. Phys. 2020, 22, 20037-20042.

29. Burrows, C. J.; Muller, J. C., Oxidative Nucleobase Modifications Leading to Strand Scission. Chem. Rev. 1998, 98, 11091151. 
30. Belmadoui, N.; Climent, M. J.; Miranda, M. A., Photochemistry of a naphthalene-thymine dyad in the presence of acetone. Tetrahedron 2006, 62 (7), 1372-1377.

31. Bonancia, P.; Vayá, I.; Climent, M. J.; Gustavsson, T.; Markovitsi, D.; Jimenez, M. C.; Miranda, M. A., Excited-state interactions in diastereomeric flurbiprofen-thymine dyads. J. Phys. Chem. A 2012, 116 (35), 8807-8814.

32. Encinas, S.; Climent, M. J.; Gil, S.; Abrahamsson, U. O.; Davidsson, J.; Miranda, M. A., Singlet excited-state interactions in naphthalene-thymine dyads. ChemPhysChem 2004, 5 (11), 17041709.

33. Belmadoui, N.; Encinas, S.; Climent, M. J.; Gil, S.; Miranda, M. A., Intramolecular interactions in the triplet excited states of benzophenone-thymine dyads. Chem. Eur. J. 2006, 12, 553-561.

34. Dumont, E.; Wibowo, M.; Roca-Sanjuan, D.; Garavelli, M.; Assfeld, X.; Monari, A., Resolving the Benzophenone DNAPhotosensitization Mechanism at QM/MM Level. J. Phys. Chem. Lett. 2015, 6 (4), 576-580.

35. Delatour, T.; Douki, T.; D'Ham, C.; Cadet, J., Photosensitization of thymine nucleobase by benzophenone through energy transfer, hydrogen abstraction and one-electron oxidation. J. Photochem. Photobiol. B 1998, 44, 191-198.

36. Tamai, N.; Asahi, T.; Masuhara, H., Intersystem crossing of benzophenone by femtosecond transient grating spectroscopy. Chem. Phys. Lett. 1992, 198, 413-418.
37. Gut, I. G.; Wood, P. D.; Redmond, R. W., Interaction of Triplet Photosensitizers with Nucleotides and DNA in Aqueous Solution at Room Temperature. J. Am. Chem. Soc. 1996, 118, 2366-2373.

38. Miró, P.; Gómez-Mendoza, M.; Sastre, G.; Cuquerella, M. C.; Miranda, M. A.; Marín, M. L., Generation of the Thymine Triplet State by Through-Bond Energy Transfer. Chem. Eur. J. 2019, 25, 7004-7011.

39. Joseph, A.; Prakash, G.; Falvey, D. E., Model studies of the (6-4) photoproduct photolyase enzymz: laser flash photolysis experiments confirm radical ion intermediates in the sensitized repair of thymine oxetane adducts. J. Am. Chem. Soc. 2000, 122, 11219-11225.

40. Martinez, L. J.; Scaiano, J. C., Transient intermediates in the laser flash photolysis of ketoprofen in aqueous solution: unusual photochemistry of the benzophenone chromophore. J. Am. Chem. Soc. 1997, 119, 11066-11070.

41. Pérez-Ruiz, R.; Groeneveld, M.; van Stokkum, I. H. M.; Tormos, R.; Williams, R. M.; Miranda, M. A., Fast transient absorption spectroscopy of the early events in photoexcited chiral benzophenone-naphthalene dyads. Chem. Phys. Lett. 2006, 429 (1-3), 276281.

42. Martens, J.; Maison, W.; Schlemminger, I.; Westerhoff, O.; Groger, H. 2000. "Preparation of precursors for PNA monomers". WO 2000002864. 
For Table of Contents Only

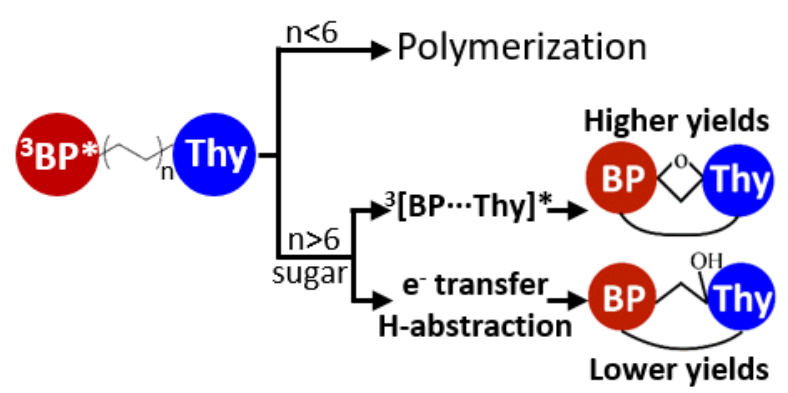

